\title{
Cesium Cobaltdicarbollide-Solubility, Precipitation, and Reactivity in Basic Aqueous Solution
}

by

D. J. McCabe

Westinghouse Savannah River Company

Savannah River Site

Aiken, South Carolina 29808

J. C. Fanning

Westinghous Savannah River Company

SC USA

L. A. Huff

Westinghouse Savannah River Company

SC USA

W. A Smith

Westinghouse Savannah River Company

SC USA

A. S. Terrell

Westinghouse Savannah River Company

SC USA

L Yasinsac

Westinghouse Savannah River Company

SC USA

L J. Todd

Westinghouse Savannah River Company SC USA

S. A. Jasper, Jr.

Westinghouse Savannah River Company

SC USA

DOE Contract No. DE-AC09-89SR1 8035

This paper was prepared in connection with work done under the above contract number with the U.S.

Department of Energy. By acceptance of this paper, the publisher and/or recipient acknowledges the U.S.

Government's right to retain a nonexclusive, royalty-free license in and to any copyright covering this paper, along with the right to reproduce and to authorize others to reproduce all or part of the copyrighted paper.

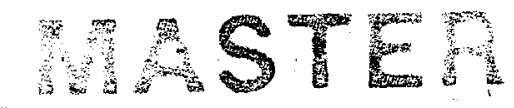




\section{DISCLAIMER}

This report was prepared as an account of work sponsored by an agency of the United States Government. Neither the United States Government nor any agency thereof, nor any of their employees, makes any warranty, express or implied, or assumes any legal liability or responsibility for the accuracy, completeness, or usefulness of any information, apparatus, product, or process disclosed, or represents that its use would not infringe privately owned rights. Reference herein to any specific commercial product, process, or service by trade name, trademark, manufacturer, or otherwise does not necessarily constitute or imply its endorsement, recommendation, or favoring by the United States Government or any agency thereof. The views and opinions of authors expressed herein do not necessarily state or reflect those of the United States Government or any agency thereof.

This report has been reproduced directly from the best available copy.

Available to DOE and DOE contractors from the Office of Scientific and Technical Information, P.O. Box 62, Oak Ridge, TN 37831; prices available from (615) 576-8401.

Available to the public from the National Technical Information Service, U.S. Department of Commerce, 5285 Port Royal Road, Springfield, VA 22161. 


\section{DISCLAIMER}

\section{Portions of this document may be illegible in electronic image products. Images are produced from the best available original document.}




\title{
Draft Copy
}

For review with possible publication in Polyhedron.

Sent to SRS for approval.

\section{CESIUM COBALTDICARBOLLIDE - SOLUBILITY, PRECIPITATION, AND REACTIVITY IN BASIC AQUEOUS SOLUTION}

\author{
JAMES C. FANNING*, LISA A. HUFF, WENDY A. SMITH, \\ AMY S. TERRELL, LESLIE YASINSAC \\ Department of Chemistry, Clemson University, Clemson, SC 29634
}

and

LEE J. TODD*, STEVE A. JASPER, Jr.

Department of Chemistry, Indiana University, Bloomington, IN 47405

and

\section{DANIEL J. MCCABE*}

Westinghouse Savannah River Company, Aiken, SC 29803

DISTRIBUTION OF THIS DOCUMENT IS UNLIMITED 
Abstract - The title compound, $\mathrm{Cs}^{+}\left[\mathrm{Co}\left((3)-1,2-\mathrm{C}_{2} \mathrm{~B}_{9} \mathrm{H}_{11}\right)_{2}\right]^{-}(\mathrm{CsCDC})$, was precipitated with a $\mathrm{NaCDC}$ solution from solutions containing $\mathrm{CsCl}$. The reaction was followed by measuring the loss of light intensity as the precipitate formed. The $\left[\mathrm{Cs}^{+}\right]$and $\left[\mathrm{CDC}^{-}\right]$at the point of precipitation were estimated and approximate values of the $\mathrm{K}_{\mathrm{sp}}$ for CsCDC determined at room temperature: $8 \times 10^{-6}$ (water), $7 \times 10^{-6}(1 \mathrm{M} \mathrm{NaOH}$ ), and $2 \mathrm{x}$ $10^{-6}(5 \mathrm{M} \mathrm{NaCl} / 0.1 \mathrm{M} \mathrm{KOH} / 1.0 \mathrm{M} \mathrm{NaOH})$. In some cases, $\mathrm{NaCDC}$ precipitated from solution when added to the latter salt solution. For the medium, $5 \mathrm{M} \mathrm{NaNO}_{3} / 0.1 \mathrm{M}$ $\mathrm{KOH} / 1.0 \mathrm{M} \mathrm{NaOH}$, a four-fold excess of $\mathrm{NaCDC}$ was added to a $10 \mathrm{mM} \mathrm{Cs}^{+}$solution at $40^{\circ} \mathrm{C}$ and the $\left[\mathrm{CDC}^{-}\right]$measured spectrophotometrically. Only $\mathrm{CsCDC}$ precipitated, and a $\mathrm{K}_{\mathrm{sp}}$ of $3.9 \times 10^{-6}$ was determined. The solubilities of $\mathrm{CsCDC}$ were measured in $\mathrm{NaNO}_{3}$ and $\mathrm{NaCl}$ solutions at $30^{\circ} \mathrm{C}$ as a function of the $\mathrm{Na}$ salt concentration. The reaction of the $\mathrm{CDC}^{-}$with $\mathrm{OH}^{-}$slowly produces $\mathrm{B}(\mathrm{OH})_{4}^{-}, \mathrm{H}_{2}$, and $\mathrm{CoO}(\mathrm{OH})$. The reaction of $22 \mu \mathrm{M}$ $\mathrm{CsCDC}$ with $1 \mathrm{M} \mathrm{NaOH}$ has a first order rate constant at $56^{\circ} \mathrm{C}$ of $8.8 \times 10^{-7} \mathrm{~s}^{-1}$, while that for $14 \mathrm{mM} \mathrm{NaCDC}$ is $7.2 \times 10^{-7} \mathrm{~s}^{-1}$. The activation energy for the reaction is 110 kJ. 
The removal of radioactive ${ }^{137} \mathrm{Cs}+1$ ions from nuclear waste solution is a major environmental problem. The removal may be achieved by ion exchange, extraction or precipitation. ${ }^{1}$ Considerable information is available on the first two methods, but little attention has been given to precipitation, even though this is the method to be used to separate ${ }^{137} \mathrm{Cs}$ from the approximately 121 million liters of nuclear waste at the Savannah River Site (SRS). The tetraphenylborate anion, $\mathrm{B}\left(\mathrm{C}_{6} \mathrm{H}_{5}\right)_{4}{ }^{-}\left(\mathrm{TPB}^{-}\right)$, is scheduled to be the precipitating agent, but there may be other anions that should be considered since problems are associated with the use of TPB $^{-}$, one being the slow formation of environmentally harmful benzene through the breakdown of TPB- by radiation. 2,3

A possible $\mathrm{Cs}^{+}$precipitating agent is $\left[\mathrm{Co}\left((3)-1,2-\mathrm{C}_{2} \mathrm{~B}_{9} \mathrm{H}_{11}\right)_{2}\right]^{-}\left(\mathrm{CDC}^{-}\right)$. This boron cluster species with a $\pi$-bonded $\mathrm{Co}$ (III) ion recently has been pointed out to have many potential uses. ${ }^{4}$ It has been utilized on a large scale to extract $\mathrm{Cs}^{+}$from acidic aqueous solution into nitrobenzene. ${ }^{5} \mathrm{CsCDC}$ has a solubility in water of $0.975 \mathrm{mM}$ at $23^{\circ} \mathrm{C} 6$ while CsTPB has a solubility of $0.028 \mathrm{mM}$ at $20^{\circ} \mathrm{C}{ }^{7}$ Even though $\mathrm{CsCDC}$ is more soluble than CsTPB, there is little possibility of forming environmentally harmful materials in waste processing,because no harmful volatiles are produced. The ability of $\mathrm{CDC}^{-}$to precipitate $\mathrm{Cs}^{+}$in aqueous solution and the solubility of $\mathrm{CsCDC}$ have been investigated and the results are reported here. Since the SRS waste is basic ( $\mathrm{pH} \sim 14)$ and concentrated in $\mathrm{NaNO}_{3}(\sim 5 \mathrm{M})$, it is necessary for this study to incorporate these conditions.

Even though $\mathrm{CDC}^{-}$has been reported to "withstand boiling with $5 \mathrm{M}$ non-oxidizing acids as well as with up to $30 \%$ alkali hydroxides for many hours without any change," 8 it was necessary to investigate the stability of $\mathrm{CDC}^{-}$in base solution over long periods of time. This report examines the reaction of $\mathrm{CDC}^{-}$, as $\mathrm{CsCDC}$ and $\mathrm{NaCDC}$, with $\mathrm{NaOH}$ solutions in the absence and the presence of high $\left[\mathrm{NO}_{3}{ }^{-}\right]$.

\section{EXPERIMENTAL}

\section{Chemicals}

CsCDC was obtained from Boron Biologicals, Inc. Raleigh, NC. A solution of $\mathrm{NaCDC}$ was prepared by passing a nearly saturated (ca. $0.9 \mathrm{mM}$ ) CsCDC solution over a cation exchange resin, which had been washed with a concentrated $\mathrm{NaCl}$ solution. The resulting solution, which was concentrated by boiling, had a $\left[\mathrm{Cs}^{+}\right]$below the detection limit of the ion chromatograph. The $\mathrm{CDC}^{-}$has bands at 281 ( $\left.\varepsilon 35000\right)$ and $445 \mathrm{~nm}(\varepsilon 420$ $\mathrm{M}^{-1} \mathrm{~cm}^{-1}$ ), both of which obey Beer's Law. The $445 \mathrm{~nm}$ peak obeys Beer's law in solutions with high $\left[\mathrm{OH}^{-}\right]$and $\left[\mathrm{NO}_{3}^{-}\right] . \mathrm{NaOH}$ was the source of hydroxide. 
The $\mathrm{Cs}$ salt of hexabrominated $\mathrm{CDC}^{-}(\mathrm{CsBCDC}), \mathrm{Cs}^{+} \mathrm{Co}\left(\mathrm{C}_{2} \mathrm{~B}_{9} \mathrm{H}_{8} \mathrm{Br}_{3}\right)_{2}^{-}$, was prepared by the procedure of Hawthorne et al. ${ }^{9}$ with a yield of $84 \%$ using $\mathrm{CsCDC}$ instead of $\mathrm{RbCDC}$ in the bromination reaction. The compound had a UV band at $295 \mathrm{~nm}$ $\left(13,000 \mathrm{M}^{-1} \mathrm{~cm}^{-1}\right) .{ }^{1}{ }_{\mathrm{B}} \mathrm{NMR}$ (acetone): $\delta 6.0$ (singlet), 4.0, -1.3(singlet), $-4.3,-16.8$ and -23.0 , with a relative area ratio $1: 1: 2: 2: 2: 1$, respectively.

\section{Instrumentation}

(a) A Shimadzu UV-3100 recording spectrophotometer was used to record the UV-visible spectra.

(b) ${ }^{1} \mathrm{~B}$ NMR spectra were obtained at $115.85 \mathrm{MHz}$ with a Nicolet NT-360 spectrometer which was externally referenced to $\mathrm{BF}_{3} \cdot \mathrm{OEt}_{2}$. Positive shift values were downfield. (c) A Dionex 2003i ion chromatography system was used to obtain the $\left[\mathrm{Cs}^{+}\right]$of the solutions. A volume of $1 \mathrm{~mL}$ was injected into the instrument which had a $50 \mathrm{~mL}$ sample loop and an IonPac CS-10 column. The eluent was a $4 \mathrm{mM}$ 2,3-diaminopropionic acid monohydrochloride (Aldrich) $/ 40 \mathrm{mM} \mathrm{HCl}$ solution. A flow rate of $1 \mathrm{~mL} / \mathrm{min}$ was used with suppressed conductivity being the detection mode. These are the approximate elution times (min): $\mathrm{Na}^{+}, 2 ; \mathrm{K}^{+}, 3$; and $\mathrm{Cs}^{+}, 4$. In order to detect $1 \mathrm{mM} \mathrm{Cs}^{+}$or less, the $\left[\mathrm{Na}^{+}\right]$and $\left[\mathrm{K}^{+}\right]$had to be less than $50 \mathrm{mM}$. This placed a severe restriction on the use of ion chromatography since the detection limit of $\mathrm{Cs}^{+}$was about $0.01 \mathrm{mM}$.

(d) A Gow-Mac 580 Gas Chromatograph with a Supelco 60/80 molecular sieve 5A column ( $3 \mathrm{ft} \times 1 / 8$ in) was used to detect the presence of $\mathrm{H}_{2}$ and was operated under the following conditions: column, detector and injector temperatures, $23^{\circ} \mathrm{C}$; He flow rate, 60 $\mathrm{mL} / \mathrm{min}$; attentuation, $1 \mathrm{X}$; and detector current, $250 \mathrm{~mA}$.

(e) The black product obtained from the reaction of $\mathrm{CDC}^{-}$with base was identified as $\mathrm{Co}(\mathrm{O}) \mathrm{OH}$ by $\mathrm{Dr}$. William Pennington at Clemson University using a Scintag $\mathrm{X}$-ray powder diffractometer.

\section{Typical precipitation experiment}

An solution $(25 \mathrm{~mL})$ of $10 \mathrm{mM} \mathrm{CsCl}$ was prepared using water or a given medium as solvent, and $2 \mathrm{~mL}$ were removed for the spectrophotometer reference. The precipitating agent $(0.075 \mathrm{M} \mathrm{NaCDC})$ was added in $0.1 \mathrm{~mL}$ increments to the stirring solution. After each increment was added, the solution was allowed to stir for five minutes before the $\% \mathrm{~T}$ of a $2 \mathrm{~mL}$ aliquot was measured at $600 \mathrm{~nm}$ using a B\&L Spectronic 20. As the precipitate formed, the turbidity of the solution increased, and the $\% \mathrm{~T}$ decreased. This procedure 
was continued until one equivalent of precipitating agent $(3.1 \mathrm{~mL})$ was added. When complete, the flask was sealed, and the solution allowed to stir for more than $24 \mathrm{~h}$. The solution was then filtered. The resulting solid was washed with cold water and dried in air at $110^{\circ} \mathrm{C}$. The fraction of $\mathrm{Cs}$ precipitated in the experiment was determined from the mass of the CsCDC collected and the theoretical mass possible. The UV-visible spectrum of the solution and, if possible, the $\left[\mathrm{Cs}^{+}\right]$were measured.

\section{Solubility Measurements}

A saturated $\mathrm{CsCDC}$ solution with excess solid was prepared in a sealed flask. The mixture was placed into a temperature-controlled water bath with a shaker attachment. After several days of slow shaking, the solution was removed from the bath and the UVvisible spectrum of the filtered solution obtained. The $\left[\mathrm{Cs}^{+}\right]$in some solutions was measured using ion chromatography.

\section{Rate studies}

(a) Solid $\mathrm{CsCDC}$, or an appropriate volume of $\mathrm{NaCDC}$ solution, was added to enough $\mathrm{NaOH}$ solution to obtain $50 \mathrm{~mL}$ of the desired [CDC-] and $\left[\mathrm{OH}^{-}\right]$. In some cases, solid $\mathrm{NaNO}_{3}$ was added to produce a given $\left[\mathrm{NO}_{3}{ }^{-}\right]$. The solution was placed in a shaking water bath at the required temperature and aliquots were removed at regular time intervals. They were cooled to room temperature and a UV-visible spectrum was taken of each. The absorbance (A) was measured at $281 \mathrm{~nm}$, or if $\mathrm{NO}_{3}{ }^{-}$was present, at $445 \mathrm{~nm}$. To obtain the first order rate constant $(k)$ a plot was made of the $\ln (\mathrm{A})$ vs. the time the sample spent in the water bath.

(b) A solution of $\mathrm{NaCDC}$ (ca. $14 \mathrm{mM}$ ) was prepared with $1.0 \mathrm{M} \mathrm{NaOH}$ and the ${ }^{11_{\mathrm{B}} \mathrm{nmr}}$ spectrum measured at various times with the sample at $56^{\circ} \mathrm{C}$. The area of the $\mathrm{B}(\mathrm{OH})_{4}^{-}$ peak $(+1.52 \mathrm{ppm})$ was determined for each spectrum and the $\%$ of the total B present as $\mathrm{CDC}^{-}(\mathrm{P})$ calculated. The value of $\mathrm{k}$ was calculated from the plot of $\ln (\mathrm{P})$ vs. time.

\section{$\mathrm{H}_{2}$ as a product}

The reaction was carried out three times on a vacuum line in order to detect and determine the amount of $\mathrm{H}_{2}$ generated. The experiments used a $88.2 \mathrm{~mL}$ vessel containing $0.20 \mathrm{~g}$ of $\mathrm{CsCDC}$ and $25 \mathrm{~mL}$ of $1.0 \mathrm{M} \mathrm{NaOH}$. The container was evacuated three times with a "freeze-thaw" procedure and sealed with a stopcock. After remaining 
in a $65^{\circ} \mathrm{C}$ bath for several days, the solution was cooled to freezing temperature and the vessel opened to the manometer. The pressure of the gas in the vessel was measured, and a sample of the gas injected into a gc. The sample showed the presence of trace amounts of $\mathrm{H}_{2}, \mathrm{O}_{2}$ and $\mathrm{N}_{2}$. Because of the small amount of $\mathrm{H}_{2}$ produced, the gc could qualitatively detect the presence of $\mathrm{H}_{2}$, but not give the amount produced. The moles of $\mathrm{H}_{2}$ were calculated from the small pressure increase, assuming only $\mathrm{H}_{2}$ was formed. The change in the $\left[\mathrm{CDC}^{-}\right]$may be made by measuring the UV-visible spectra or by using the rate equation. The moles of $\mathrm{H}_{2}$ formed per mol of $\mathrm{CDC}^{-}$decomposed were calculated to be $0.46,0.29$ and 0.26 .

\section{RESUlTS AND DISCUSSION}

\section{Precipitation}

The precipitation of $\mathrm{Cs}^{+}$from solution with $\mathrm{CDC}^{-}$was studied with a simple, relatively inexpensive turbidimetric analysis method. 10 In this method the intensity of transmitted light through the solution $(\% \mathrm{~T})$ is measured at a non-absorbing visible wavelength $(600 \mathrm{~nm})$ as the solution of the precipitating agent $(\mathrm{NaCDC})$ is added. Unfortunately, this is not as sensitive as the nephelometric analysis method which measures the amount of light scattered at right angles to the light beam (Tyndall effect) as the precipitate forms. However, the equipment required for the turbidimetric method was more readily available. Furthermore, for this method, the precipitate needs to be one that settles relatively slowly. This is the case for the CsCDC precipitate.

As a solution of $\mathrm{NaCDC}$ is added slowly to a $\mathrm{Cs}^{+}$solution, a bright yellow precipitate forms. Once the insoluble $\mathrm{CsCDC}$ appears, the $\% \mathrm{~T}$ of the solution begins to decrease and continues to decrease as more $\mathrm{NaCDC}$ is added. At the concentrations being used, a limiting value of the $\% \mathrm{~T}(<5 \%)$ is usually reached before the equivalence point . Fig. 1 shows the turbidity measurements for solutions of $10 \mathrm{mM} \mathrm{CsCl}$ with $0.075 \mathrm{M} \mathrm{NaCDC}$ and $0.075 \mathrm{M} \mathrm{NaTPB}$ in water. The CsTPB precipitation was carried out for comparison with CsCDC. The lower solubility of CsTPB can be observed from the larger amount of precipitating agent required to initiate precipitation of $\mathrm{CsCDC}$.

The value of the $\mathrm{K}_{\mathrm{sp}}$ for $\mathrm{CsCDC}$ may be obtained from the precipitation reaction in several ways. The incipient $\mathrm{K}_{\mathrm{sp}},\left(\mathrm{K}_{\mathrm{sp}}\right)^{\text {in }}$, is found from the turbidity curve (Fig. 1) by estimating the $\left[\mathrm{Cs}^{+}\right]$and $\left[\mathrm{CDC}^{-}\right]$at the point of incipient precipitation. The absorbance $\mathrm{K}_{\mathrm{sp}},\left(\mathrm{K}_{\mathrm{sp}}\right)^{\mathrm{ab}}$, is found when some $\mathrm{CDC}^{-}$is added and the absorbance of the $\mathrm{CDC}^{-}$ remaining in solution is measured. The $\left[\mathrm{CDC}^{-}\right]$and $\left[\mathrm{Cs}^{+}\right]$are calculated assuming only 
CsCDC precipitates. A $\mathrm{K}_{\mathrm{sp}}$ based on the direct measurement of both concentrations, $\left(\mathrm{K}_{\mathrm{sp}}\right)^{\mathrm{ac}}$, is obtained if both the $\left[\mathrm{Cs}^{+}\right]$and $\left[\mathrm{CDC}^{-}\right]$can be measured by independent means. $\mathrm{A} \mathrm{K}_{\mathrm{sp}}$ based on the mass of precipitate obtained, $\left(\mathrm{K}_{\mathrm{sp}}\right)^{\mathrm{ma}}$, was determined from the fraction of $\mathrm{Cs}$ precipitated from solution. ${ }^{11}$ Since an excess of reactant ions are required to initiate precipitation, the value of $\left(\mathrm{K}_{\mathrm{sp}}\right)^{\text {in }}$ is expected to be larger than the other $\mathrm{K}_{\mathrm{sp}}$ values. 12

Precipitating $\mathrm{Cs}^{+}$from solutions with high salt concentrations limited the ways of obtaining the $\mathrm{K}_{\mathrm{sp}}$ value. The large $\left[\mathrm{Na}^{+}\right]$made it difficult to determine the $\left[\mathrm{Cs}^{+}\right]$by ion chromatography. Therefore, obtaining $\left(\mathrm{K}_{\mathrm{sp}}\right)^{\mathrm{ac}}$ in these solutions was difficult. It was also difficult to accurately obtain $\left(\mathrm{K}_{\mathrm{sp}}\right)^{\mathrm{ma}}$ since some of the precipitate was lost when it had to be washed free of salt contaimination before it was dried and weighed.

Initial studies of $\mathrm{CsCDC}$ precipitation were carried out in a chloride medium $(5 \mathrm{M}$ $\mathrm{NaCl} / 0.1 \mathrm{M} \mathrm{KOH} / 1.0 \mathrm{M} \mathrm{NaOH})$. A nitrate medium ( $5 \mathrm{M} \mathrm{NaNO}_{3} / 0.1 \mathrm{M} \mathrm{KOH} / 1 \mathrm{M}$ $\mathrm{NaOH}$ ) would have been preferable since it is similar to the SRS waste medium. Unfortunately, the nitrate ion had an intense band in the ultraviolet which interfered with the more intense $\mathrm{CDC}^{-}$band making it impossible to measure low $\left[\mathrm{CDC}^{-}\right]$in that medium. The room temperature results of precipitation experiments in water and in the chloride medium are summarized in Table 1 . Some precipitation studies were made in the nitrate medium using the much weaker band at $445 \mathrm{~nm}$ for [ $\left.\mathrm{CDC}^{-}\right]$measurements and these are described below.

In water, the precipitation of $\mathrm{CsCDC}$ gave a $\mathrm{K}_{\mathrm{sp}}$ of about $4 \times 10^{-6}$. With $10 \mathrm{mM} \mathrm{Cs}^{+}$ in the chloride medium, a lower value, $2.8 \times 10^{-7}$, was obtained. At a [CDC- $]$ of $1 \mathrm{mM}$ a large amount of precipitate formed. This happened even when no $\mathrm{Cs}$ was present in solution. Apparently, the solubility of $\mathrm{NaCDC}$ decreases in the highly concentrated salt solutions. If it is assumed that only $\mathrm{NaCDC}$ precipitates, then the $\mathrm{K}_{\mathrm{sp}}$ of $\mathrm{NaCDC}$ is about $1 \times 10^{-3}$. Using this value, the solubility of $\mathrm{NaCDC}$ in the medium can be calculated to be about $0.03 \mathrm{M}$.

Room temperature precipitation of $\mathrm{CsCDC}$ in the nitrate medium could not be carried out since $\mathrm{NaCDC}$ precipitated when small amounts of a highly concentrated $\mathrm{NaCDC}$ solution in water were added; however, this was not the case at $40^{\circ} \mathrm{C}$. An experiment was carried out in which $5.1 \mathrm{~mL}$ of a $0.2 \mathrm{M} \mathrm{NaCDC}$ solution was added to a $25 \mathrm{~mL}$ solution of $10 \mathrm{mM} \mathrm{CsNO}_{3}$, which was being stirred at $40^{\circ} \mathrm{C}$. After stirring for $30 \mathrm{~min}$, the solution was filtered, the precipitate washed with a small amount of water and the [CDC-] determined in the filtrate was $0.6 \mathrm{mM}$. The precipitate was dried in air at $110^{\circ} \mathrm{C}$ and weighed ( $36.6 \pm 0.5 \mathrm{mg}$ - avg. of three experiments). A portion of the precipitated product was redissolved in water and the $\left[\mathrm{Cs}^{+}\right]$and $\left[\mathrm{CDC}^{-}\right]$were measured. The 
precipitate was $29.1 \% \mathrm{Cs}$ and $71.6 \% \mathrm{CDC}^{-}$. Pure CsCDC is $29.1 \% \mathrm{Cs}$, and $70.9 \% \mathrm{CDC}$. Ion chromatography showed that the precipitate had no $\mathrm{Na}$ or $\mathrm{K}$ present. Therefore, $\mathrm{NaCDC}$ precipitation does not occur at $40^{\circ} \mathrm{C}$ in the nitrate medium when up to four equivalents of $\mathrm{NaCDC}$ solution is used; the precipitate contains only $\mathrm{CsCDC}$. The value of $\left(\mathrm{K}_{\mathrm{sp}}\right)^{\mathrm{ab}}$ for the three experiments was $(3.9 \pm 0.5) \times 10^{-6}$, while the value for $\left(\mathrm{K}_{\mathrm{sp}}\right)^{\mathrm{ma}}$ was $(1.4 \pm 0.1) \times 10^{-6}$. Mass balance was achieved with $\mathrm{CDC}^{-}$in the filtrate, precipitate and wash solutions.

\section{Solubility}

Precipitation experiments showed that the solubility of CsCDC was not the same in water, the nitrate medium and chloride medium. Because of these differences in CsCDC solubility, saturated $\mathrm{CsCDC}$ solutions were prepared at $30^{\circ} \mathrm{C}$ with either $\mathrm{NaCl}$ or $\mathrm{NaNO}_{3}$ present. ' The $\left[\mathrm{CDC}^{-}\right]$was measured by UV-visible spectroscopy, using a range of salt concentrations ( 0 to $4 \mathrm{M} \mathrm{NaCl}$ and 0 to $5 \mathrm{M} \mathrm{NaNO}_{3}$ ). In Fig. 2, the logarithm of the $\mathrm{CsCDC}$ solubilities is plotted versus the square root of the ionic strength of the solutions. At low salt concentrations $(<0.1 \mathrm{M})$, the Debye-Huckel limiting law is followed. There is some scatter in the data points due primarily to the low precision of the absorbance measurements. The solubility of $\mathrm{CsCDC}$ in $4 \mathrm{M} \mathrm{NaCl}$ is about a third less than it is in water, while in $5 \mathrm{M} \mathrm{NaNO}$ the solubility is slightly greater than in water.

The behavior of the $\mathrm{CsCDC}$ solubility with changes in the ionic strength is not very different from what might be expected with smaller, more hydrophilic anions. In Fig. 2 the solubility increases as the ionic strength increases, but then reaches a maximum value and begins to decrease. The two salt curves show basically the same behavior. But, the nitrate curve has a smaller curvature than that of the chloride curve.

The shape of the curves is similar to those found when the logarithm of the solubility of $\mathrm{BaSO}_{4}$ is plotted versus the ionic strength for a variety of salts. ${ }^{13}$ Even though $\mathrm{BaSO}_{4}$ is a $+2 /-21: 1$ salt, it has about the same solubility behavior as $\mathrm{CsCDC}$. Unfortunately, no nitrates were used to provide the ionic strength in the $\mathrm{BaSO}_{4}$ study, just several chlorides $\left(\mathrm{NaCl}, \mathrm{KCl}, \mathrm{CaCl}_{2}\right.$, and $\left.\mathrm{MgCl}_{2}\right)$, a bromide $(\mathrm{KBr})$ and a borate $\left(\mathrm{Na}_{2} \mathrm{~B}_{4} \mathrm{O}_{7}\right)$. All of the univalent cation and anion pairs showed about the same effect in changing the solubility of the $\mathrm{BaSO}_{4}$. 


\section{Hydroxide Reactivity}

Since the formation of the $\mathrm{CDC}^{-}$anion is carried out in strong base solution, it was felt that it should have considerable base stability. The carborane ligand is formed by reacting 1,2-carborane with methanolic $\mathrm{KOH}$ at $40^{\circ} 14$.

$$
1,2-\mathrm{B}_{10} \mathrm{C}_{2} \mathrm{H}_{12}+2 \mathrm{OH}^{-}+2 \mathrm{H}_{2} \mathrm{O} \rightarrow\left[7,8-\mathrm{B}_{9} \mathrm{C}_{2} \mathrm{H}_{12}^{-}\right]+\mathrm{H}_{2}+\mathrm{B}(\mathrm{OH})_{4}^{-}
$$

The ions are then reacted with $\mathrm{CoCl}_{2}$ in concentrated base ${ }^{9}$ to form $\mathrm{CDC}^{-}$:

$$
\begin{aligned}
& {\left[7,8-\mathrm{B}_{9} \mathrm{C}_{2} \mathrm{H}_{12}{ }^{-}\right]+\mathrm{OH}^{-} \rightarrow\left[7,8-\mathrm{B}_{9} \mathrm{C}_{2} \mathrm{H}_{11}{ }^{-2}\right]+\mathrm{H}_{2} \mathrm{O}} \\
& {\left[7,8-\mathrm{B}_{9} \mathrm{C}_{2} \mathrm{H}_{11^{-2}}\right]+1.5 \mathrm{CoCl}_{2} \rightarrow\left[\mathrm{Co}\left((3)-1,2-\mathrm{C}_{2} \mathrm{~B}_{9} \mathrm{H}_{11}\right)_{2}\right]^{-}+0.5 \mathrm{Co}^{0}+3 \mathrm{Cl}^{-}}
\end{aligned}
$$

Reports have shown that neutral carboranes react with basic solutions. Wiesboek and Hawthorne ${ }^{15}$ studied the reaction of the carborane in $50 \% \mathrm{EtOH}-\mathrm{H}_{2} \mathrm{O}$ at $75^{\circ}$ and established the following rate expression for the decomposition:

$$
\text { Rate }=1.48 \times 10^{-3} 1 \mathrm{~mol}^{-1} \mathrm{~s}^{-1}\left[1,2-\mathrm{B}_{10} \mathrm{C}_{2} \mathrm{H}_{12}\right]\left[\mathrm{EtO}^{-}\right]
$$

If the [EtO-] is $1 \mathrm{M}$ then the half-life would be $1.5 \mathrm{~h}$. The $1,7.16$ and $1,12.17$ carboranes react more slowly with base since very rigorous conditions are required to remove one $\mathrm{B}$ atom from each cluster.

When $\mathrm{CsCDC}$ or $\mathrm{NaCDC}$ is dissolved in base solution, the solution may be yellow, orange to dark brown, depending on [CDC-]. As the reaction takes place, the solution slowly becomes colorless and a black solid appears. In all experiments with [ $\left.\mathrm{CDC}^{-}\right]$of $10^{-5} \mathrm{M}$ at temperatures less than $65^{\circ} \mathrm{C}$, trace amounts of a white precipitate were observed after about $20 \%$ of the $\mathrm{CDC}^{-}$had reacted. The white precipitate appeared before the black precipitate was observed. In attempting to form more of the white precipitate, $0.5 \mathrm{mmol}$ of $\mathrm{CsCDC}$ was placed in $50 \mathrm{~mL}$ of $3 \mathrm{M} \mathrm{NaOH}$ and heated to $100^{\circ} \mathrm{C}$ for $13 \mathrm{~h}$. The $\mathrm{CsCDC}$ completely dissolved, but no white precipitate was observed, only black precipitate and a dark brown solution.

Some of the reaction products have been identified. The black precipitate was isolated from one of the reactions, washed with water and dried. A sample of the black powder had an X-ray powder diffraction pattern that matched that of $\mathrm{Co}(\mathrm{O}) \mathrm{OH}$. The ${ }^{11} \mathrm{~B} \mathrm{nmr}$ spectra showed that $\mathrm{B}(\mathrm{OH})_{4}{ }^{-}$is the final product for all of the boron. The intermediate 
white precipitate was probably $\mathrm{CsB}_{9} \mathrm{C}_{2} \mathrm{H}_{12}$ which has the protonated ligand of $\mathrm{CDC}^{-} .14$ However, it was not specifically identified; not enough could be recovered to be analyzed. One experiment which was carried out with $1 \mathrm{M} \mathrm{NaOH}$ at $65^{\circ} \mathrm{C}$ and monitored by ion chromatography, showed that over a seven day period the $\left[\mathrm{Cs}^{+}\right]$decreased from $0.92 \mathrm{mM}$ to $0.25 \mathrm{mM}$.

In examining $\mathrm{H}_{2}$ as a product, the small pressure increase (10-20 torr, measured for the three similar experiments) was assumed to be due exclusively to $\mathrm{H}_{2}$ production. These amounts were produced over long periods of time, which might have led to the lack of precision in the amount of $\mathrm{H}_{2}$ measured. However, leaks in the container did not seem to be a problem since the pressure was always much less than atmospheric pressure and tests without $\mathrm{H}_{2}$ showed no leaking. The mole ratio of $\mathrm{H}_{2}$ to $\mathrm{CDC}^{-}$decomposed for all of the experiments was less than one. With $\mathrm{B}(\mathrm{OH})_{4}^{-}$as the end product of $\mathrm{B}$, a much larger value was expected. The reason for the small amount of $\mathrm{H}_{2}$ produced is not known.

The two UV-visible absorption bands of $\mathrm{CDC}^{-}(281$ and $445 \mathrm{~nm})$ may be used to follow the loss of $\mathrm{CDC}^{-}$during the reaction. For dilute solutions with no nitrate present, the more sensitive $281 \mathrm{~nm}$ band may be used. With nitrate present, the $445 \mathrm{~nm}$ band was used to follow the reaction. As the reaction went to completion no new band appeared, until after about nine half-lives, a weak band at $360 \mathrm{~nm}$ began to form. Attempts were made to use procedures that took into account a change in the spectral baseline with time ${ }^{18}$, but the data were not affected by these corrections. When the reaction was carried out at $75^{\circ}$, the $360 \mathrm{~nm}$ peak appeared much earlier in the course of the reaction.

All of the reactions were carried out with an excess of $\mathrm{OH}^{-}$present and the decrease in $\left[\mathrm{CDC}^{-}\right]$followed. The decrease obeyed first order kinetics and the rate constants $(\mathrm{k})$ and half-lives for $\mathrm{CDC}^{-}$decomposition at essentially constant $\left[\mathrm{OH}^{-}\right]$are given in Table 2 . The temperature, $\left.\left[\mathrm{OH}^{-}\right], \mathrm{NO}_{3}^{-}\right]$and $\mathrm{CDC}^{-}$counterion were varied. From a plot of $\ln (\mathrm{k})$ vs. $1 / \mathrm{T}(\mathrm{K})$ the following Arrehnius expression was found:

$$
\ln (\mathrm{k})=34.4-1.33 \times 10^{4}(1 / \mathrm{T})
$$

leading to an activation energy of $110 \mathrm{~kJ} / \mathrm{mol} \mathrm{CDC}^{-}$.

A fractional order of 1.26 for $\mathrm{OH}^{-}$was obtained from the slope of the graph obtained by plotting $\ln \mathrm{k}\left(\right.$ at $65^{\circ}$ ) vs. $\ln \left[\mathrm{OH}^{-}\right]$. Therefore, with the large excess of $\mathrm{OH}^{-}$, the rate law is

$$
\text { Rate }=k_{\mathrm{o}}\left[\mathrm{CDC}^{-}\right]\left[\mathrm{OH}^{-}\right]^{1.26}=\mathrm{k}\left[\mathrm{CDC}^{-}\right]
$$


Varying $\left[\mathrm{NO}_{3}^{-}\right]$from 0 to $5 \mathrm{M}$ and using $\mathrm{Na}^{+}$instead of $\mathrm{Cs}^{+}$showed no major effect on the value of $\mathrm{k}$. Using the rate and activation energy equations, the half-life of $\mathrm{CDC}^{-}$at $25^{\circ}$ in $1 \mathrm{M} \mathrm{OH}^{-}$was estimated to be 2.2 years.

Fig. 3 shows first-order plots for the $56^{\circ}$ decomposition of $22 \mu \mathrm{M} \mathrm{CsCDC}$ and 14 $\mathrm{mM} \mathrm{NaCDC}$ in $1 \mathrm{M} \mathrm{OH}^{-}$. The former was determined using UV-visible spectroscopy, while the latter was determined with NMR. The rates are close, but the higher concentration of $\mathrm{CDC}^{-}$shows a slightly smaller $\mathrm{k}$ value.

Since the reported solubility of the hexabromo compound, $\mathrm{CsBCDC}$, in water is $3 \mathrm{x}$ $10^{-4} \mathrm{M}^{8}$, which is lower than that of $\mathrm{CsCDC}$, a small amount of $\mathrm{CsBCDC}$ was prepared 9 and the decomposition reaction carried out at $65^{\circ}$ in $1 \mathrm{M} \mathrm{NaOH}$. A $67 \mu \mathrm{M} \mathrm{CsBCDC}$ solution had a $\mathrm{k}$ value of $1.1 \times 10^{-4} \mathrm{~s}^{-1}$ or a $1.75 \mathrm{~h}$ half-life. For a similar solution of $\mathrm{CsCDC}$ the value of $\mathrm{k}$ is $20 \times 10^{-7} \mathrm{~s}^{-1}$ or a $98 \mathrm{~h}$ half-life. Substitution of three $\mathrm{Br}$ atoms for three $\mathrm{H}$ atoms on each of the two cages produces about a fifty fold increase in the rate of base decomposition. These results are expected if the reaction occurs by the nucleophilic attack of the hydroxide ion on one of the boron hydride cages.

Even though $\mathrm{CDC}^{-}$is an inert $\mathrm{d}^{6} \mathrm{Co}$ (III) $\pi$-complex, it still lacks great stability in the basic medium. The Co(III) is converted to the oxohydroxide and the ligands attached to the metal slowly undergo decomposition. This lack of stability at high [ $\left.\mathrm{OH}^{-}\right]$probably will mean that the $\mathrm{CDC}^{-}$anion will not be able to serve as a precipitating agent for $\mathrm{Cs}^{+}$at high $\mathrm{pH}$.

\section{Conclusions}

Unfortunately, CsCDC does not have a low enough solubility or a high enough stability in aqueous base in order for $\mathrm{NaCDC}$ to be considered as a precipitating agent for $\mathrm{Cs}$ from base solution. If CsCDC was either a factor of ten less soluble in base or had a hydroxide decomposition rate constant about a hundred times smaller, the $\mathrm{CDC}^{-}$might be a satisfactory anion to use for the precipitation. It might not be necessary to have both factors operating, since a very low solubility would not provide enough dissolved precipitate for reaction. Precipitation of ${ }^{137} \mathrm{Cs}$ using a precipitating agent, which forms a Cs salt with a higher solubility than that of CsTPB and low reactivity, might be achieved by adding non-radioactive ${ }^{133} \mathrm{Cs}$ to the waste and carrying out the process in stages. Efforts are underway to find a new Cs precipitating agent . 
Acknowledgements ---The authors thank Teresa Bagwell for her assistance in synthesizing CsBCDC and examining its base stability and Jeffrey Lamb for his help with the precipitation experiments. This work was funded by the Department of Energy, Office of Technology Development, through the Westinghouse Savannah River Company in cooperation with the South Carolina Universities Research and Education Foundation. 


\section{REFERENCES}

1. W.W. Schulz and L.A. Bray, Separation Science and Technology, 1987, 191.

2. A.K. Gupta, R.J. Hanrahan and D.D. Walker, Radiochem. Acta, 1993, 60, 42.

3. A. K. Gupta, R.J. Hanrahan and D.D. Walker, J. Phys. Chem., 1991, 95, 3590.

4. J. Plesek, Chem. Rev., 1992, 92, 269.

5. J. Rais, E. Sebestoa, P. Selucky and M. Kyrs, J. Inorg. Nucl. Chem., 1976, 38, 1742.

6. J. Rais, P. Selucky and M. Kyrs, J. Inorg. Nucl. Chem., 1976, 38, 1376.

7. E. Siska, Magyar Kemiai Folyoirat, 1976, 82, 275.

8. J. Plesk, K. Base, F. Mares, F. Hanousek, B. Stibr and S. Hermanek, Coll. Czech. Chem. Commun., 1984, 49, 2776.

9. M.F. Hawthorne, D.C. Young, T.D. Andrews, R.L. Howe, R.L. Pilling, A.D. Pitts, M. Reintjes, L.F. Warren, Jr. and P.A. Wegner, J. Am. Chem. Soc. 1968, 90, 879.

10. A.I. Vogel, A Textbook of Quantitative Inorganic Analysis, 3rd Edn., Chap. XII, Longmans, London (1961).

11. Z.Z.Hugus, Jr. and F.C. Hentz, Jr., J. Chem. Ed., 1985, 62, 645.

12. A.G. Walton, The Formation and Properties of Precipitates, Interscience, New York, (1967).

13. J.W. Davis and A.G. Collins, Environ. Sci. Tech., 1971, 5, 1039.

14. M.F. Hawthorne, D.C. Young, P.M. Garrett, D.A. Owen, S.G. Schwerin, F.N. Tebbe and P.A. Wegner, J. Am. Chem. Soc., 1968, 90, 862.

15. R.A. Wiesboeck and M.F. Hawthorne, J. Am. Chem. Soc., 1964, 86, 1642. 
16. P.M. Garrett, F.N. Tebbe and M.F. Hawthorne, J. Am. Chem. Soc., 1964, 86, 5017.

17. J. Plesek and S. Hermanek, Chem. Ind. (London) 1973, 381.

16. B. Borderle, D. Lavabre, G. Levy and J.C. Micheau, J. Chem. Ed., 1990, 67, 459. 
Table 1 Results of Precipitation of $\mathrm{Cs}^{+}$with $\mathrm{CDC}^{-}$Solutions in Water and $\mathrm{Cl}$ Medium

\begin{tabular}{|c|c|c|c|c|c|c|c|}
\hline $\begin{array}{l}{\left[\mathrm{Cs}^{+}\right]} \\
(\mathrm{mM})\end{array}$ & Solvent & $\mathrm{PA}^{*}$ & $\begin{array}{l}{[\mathrm{PA}]} \\
{[\mathrm{mM}]}\end{array}$ & $\left(\mathrm{K}_{\mathrm{sp}}\right)^{\text {in }}$ & $\left(\mathrm{K}_{\mathrm{sp}}\right)^{\mathrm{ab}}$ & $\left(\mathrm{K}_{\mathrm{sp}}\right)^{\mathrm{ac}}$ & $* * *$ \\
\hline 10 & Water & TPB- & 75 & $<1 \times 10^{-7}$ & - & - & 1 \\
\hline 10 & Water & $\mathrm{CDC}^{-}$ & 75 & $8 \times 10^{-6}$ & - & - & 1 \\
\hline 10 & Water & $\mathrm{CDC}^{-}$ & 52 & $6 \times 10^{-6}$ & $4.5 \times 10^{-6}$ & $3.6 \times 10^{-6}$ & 2 \\
\hline 5 & Water & $\mathrm{CDC}^{-}$ & 52 & $1 \times 10^{-5}$ & $4.5 \times 10^{-6}$ & - & 1 \\
\hline 1 & Water & $\mathrm{CDC}^{-}$ & 52 & $8 \times 10^{-6}$ & - & - & 1 \\
\hline 10 & $1 \mathrm{M} \mathrm{NaOH}$ & $\mathrm{CDC}^{-}$ & 52 & $7 \times 10^{-6}$ & $1.8 \times 10^{-6}$ & - & 1 \\
\hline 10 & Cl Med. & $\mathrm{CDC}^{-}$ & 52 & $2 \times 10^{-6}$ & $2.7 \times 10^{-7}$ & $2.9 \times 10^{-7}$ & 2 \\
\hline 1 & $\mathrm{Cl} \mathrm{Med}$ & $\mathrm{CDC}^{-}$ & 46 & $1 \times 10^{-3^{* *}}$ & $1.4 \times 10^{-3}$ & - & 9 \\
\hline 0 & Cl Med & $\mathrm{CDC}^{-}$ & 46 & $1 \times 10^{-3^{* *}}$ & $1.5 \times 10^{-3}$ & - & 2 \\
\hline
\end{tabular}

* - Symbols - PA, precipitating agent; $\left(\mathrm{K}_{\mathrm{sp}}\right)^{\text {in }}, \mathrm{K}_{\mathrm{sp}}$ from reagent concentrations at point of incipient precipitation; $\left(\mathrm{K}_{\mathrm{sp}}\right)^{\mathrm{ab}}, \mathrm{K}_{\mathrm{sp}}$ from CDC absorbance value; $\left(\mathrm{K}_{\mathrm{sp}}\right)^{\mathrm{ac}}, \mathrm{K}_{\mathrm{sp}}$ from direct $[\mathrm{Cs}]$ and $\left[\mathrm{CDC}^{-}\right]$measurements; $\mathrm{Cl} \mathrm{Med}-5 \mathrm{M} \mathrm{NaCl} / 0.1 \mathrm{M} \mathrm{KOH} / 1.0 \mathrm{M}$ $\mathrm{NaOH} ; \mathrm{TPB}^{-}$, tetraphenylborate anion; $\mathrm{CDC}^{-}$, cobalt dicarbollide anion.

**- Assuming only $\mathrm{NaCDC}$ precipitates.

*** - Number of experiments carried out under these conditions. 
Table 2. Results of $\mathrm{OH}^{-}$Reaction with $\mathrm{MCDC}$.

$\begin{array}{lllllll}\mathrm{M} & \mathrm{T}\left({ }^{\circ} \mathrm{C}\right) & \begin{array}{l}{\left[\mathrm{OH}^{-}\right]} \\ (\mathrm{M})\end{array} & \begin{array}{l}{\left[\mathrm{NO}_{3}^{-}\right]} \\ (\mathrm{M})\end{array} & \begin{array}{l}\text { Initial }\left[\mathrm{CDC}^{-}\right] \\ (\mu \mathrm{M})\end{array} & \mathrm{k}\left(\mathrm{s}^{-1}\right) & \begin{array}{l}\mathrm{t}_{1 / 2} \\ (\text { days })\end{array} \\ \mathrm{Cs} & 40 & 1.0 & 0 & 19 & 0.97 \times 10^{-7} & 83 \\ \mathrm{Cs} & 56 & 1.0 & 0 & 22 & 8.8 & 9.2 \\ { }^{*} \mathrm{Na} & 56 & 1.0 & 0 & 14 \mathrm{mM}^{* *} & 7.2 & 11.1 \\ \mathrm{Cs} & 65 & 1.0 & 0 & 35 & 20 & 4.1 \\ \mathrm{Cs} & 65 & 1.0 & 0 & 1.5 \mathrm{mM}^{* *} & 19 & 4.3 \\ \mathrm{Na} & 65 & 1.0 & 0 & 19 & 17 & 4.7 \\ \mathrm{Cs} & 65 & 0.5 & 0 & 36 & 11 & 7.5 \\ \mathrm{Cs} & 65 & 2.0 & 0 & 41 & 60 & 1.3 \\ \mathrm{Cs} & 65 & 3.0 & 0 & 33 & 96 & 0.8 \\ \mathrm{Cs} & 65 & 1.0 & 1.0 & 15 & 19 & 4.4 \\ \mathrm{Cs} & 65 & 1.0 & 3.0 & 18 & 19 & 4.3 \\ \mathrm{Cs} & 65 & 1.0 & 5.0 & 16 & 18 & 4.4 \\ \mathrm{Cs} & 65 & 0.32 & 5.0 & 16 & 4.4 & 18\end{array}$

* $-\mathrm{k}$ obtained by following formation of $\left[\mathrm{B}(\mathrm{OH})_{4}\right]^{-}$using ${ }^{1} \mathrm{~B}_{\mathrm{B}} \mathrm{nmr}$ spectroscopy; other $\mathrm{k}$ values obtained by following loss of $\mathrm{CDC}^{-}$with $\mathrm{UV}$-visible spectroscopy.

** - All other concentration values are $\mu \mathrm{M}$. 


\section{FIGURE CAPTIONS}

Fig. 1. Percent transmittance of a $10 \mathrm{mM}$ solution of $\mathrm{CsNO}_{3}$ measured at $600 \mathrm{~nm}$ as 0.1 $\mathrm{mL}$ amounts of a $75 \mathrm{mM}$ solution of $\mathrm{NaCDC}(+)$ or $\operatorname{NaTPB}(\Delta)$ were added.

Fig. 2. The logarithm of the solubility of $\mathrm{CsCDC}$ at $30^{\circ} \mathrm{C}$ in solutions of $\mathrm{NaCl}(+)$ and $\mathrm{NaNO}_{3}(\Delta)$ plotted against the square root of the ionic strength.

Fig. 3. The first-order plots of the decomposition of $\mathrm{CDC}^{-}$with $22 \mu \mathrm{M} \mathrm{CsCDC}(\mathrm{O})$ and $14 \mathrm{mM} \mathrm{NaCDC}(+)$ in $1 \mathrm{M} \mathrm{OH}^{-}$at $56^{\circ} \mathrm{C}$. 


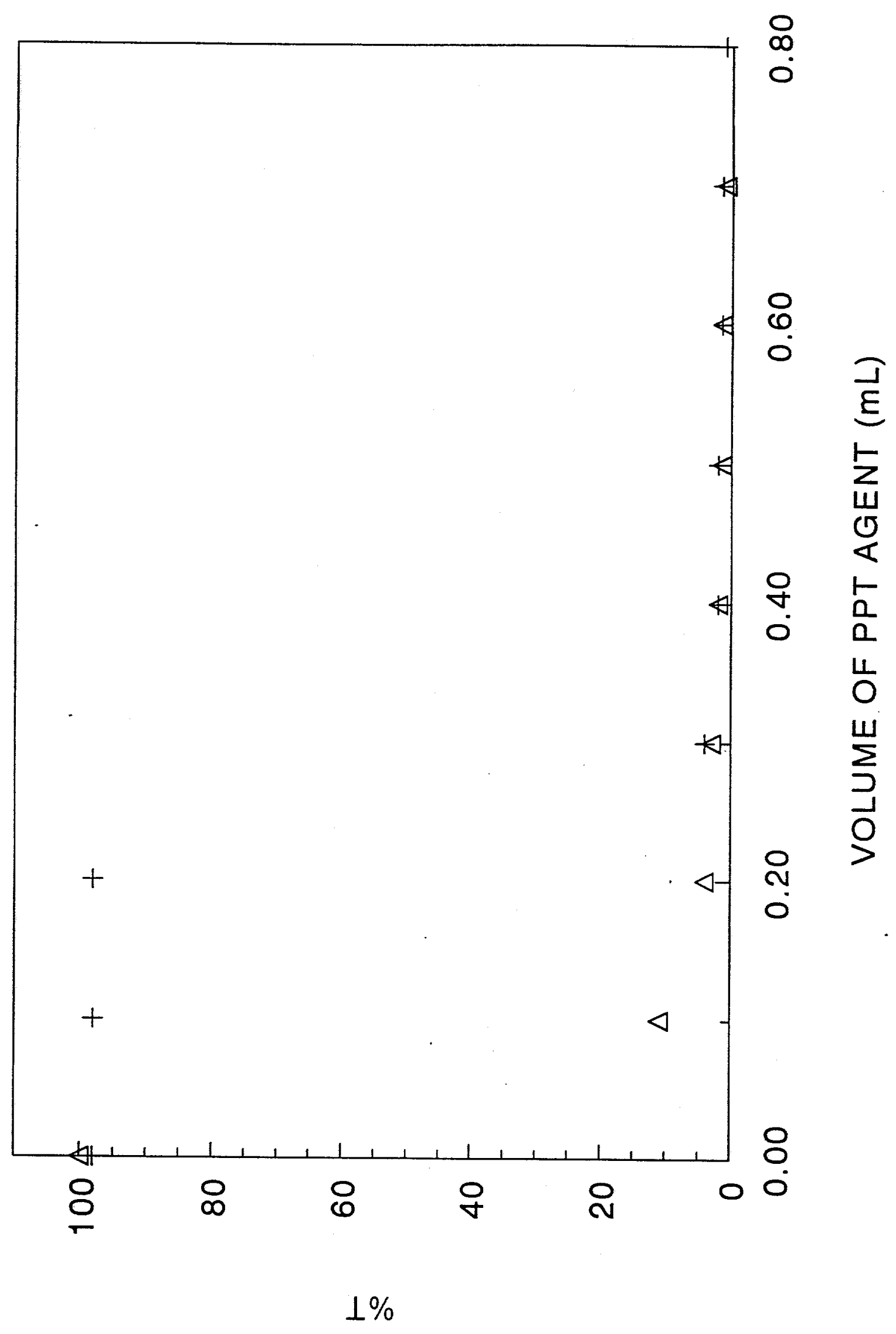




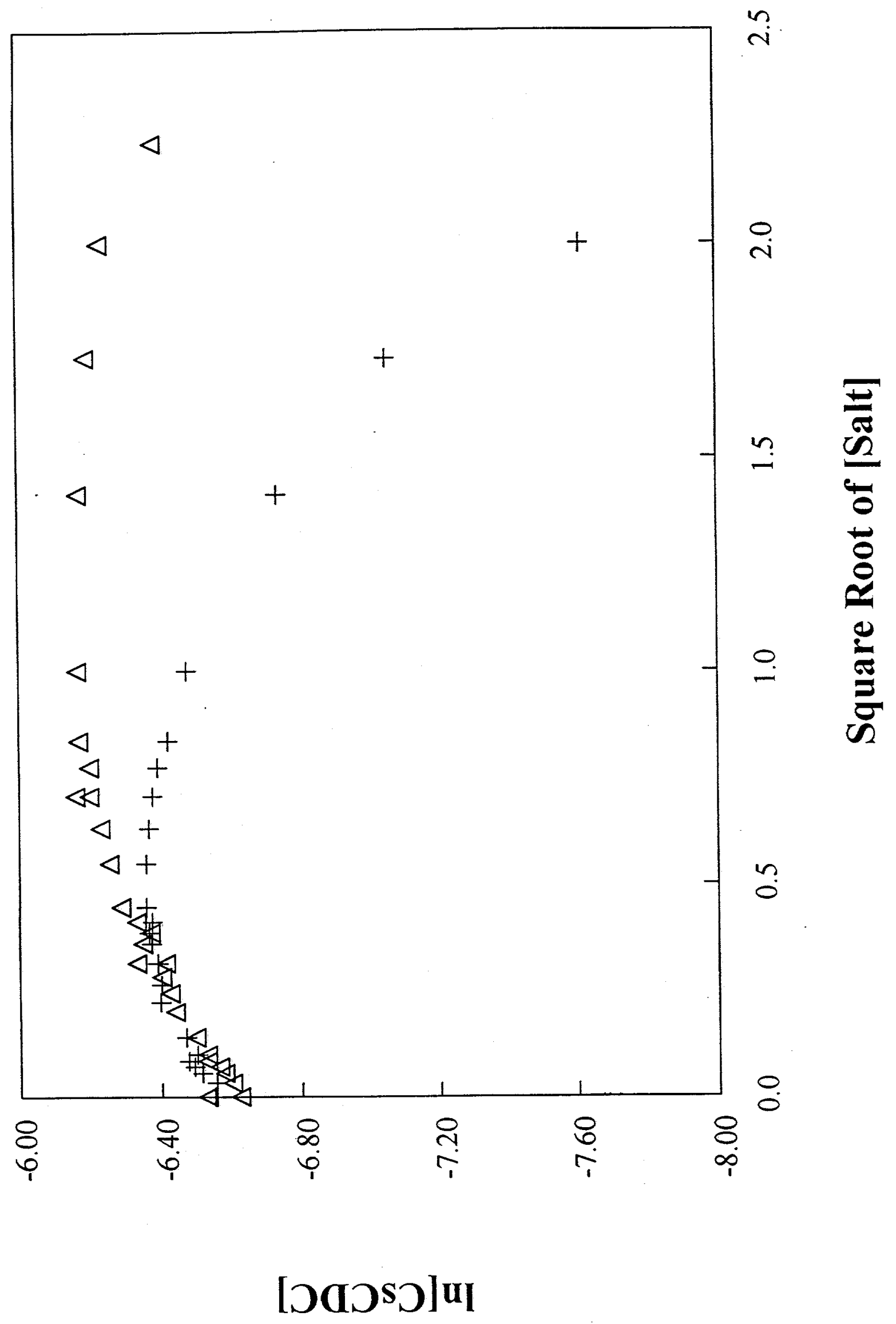


Fig. 3

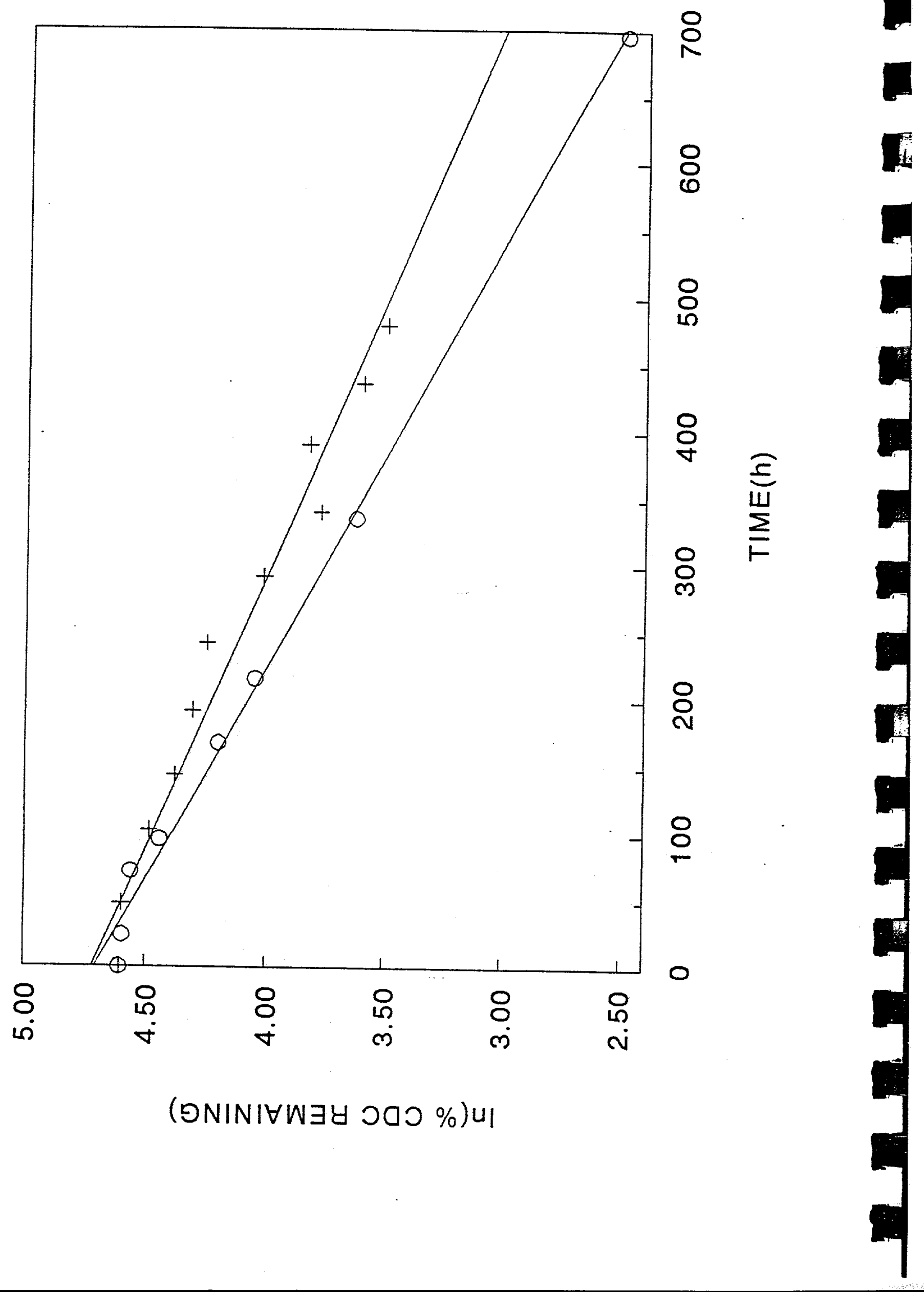

